Teknomekanik

Vol.3, No.2, December 2020, pp. 70-74

\title{
The Effect of Preheating and Non-Preheating in Cast Iron Welding toward Mechanical Properties
}

\author{
Fauzan Sauri \& Mulianti \\ Jurusan Teknik Mesin, Fakultas Teknik, Universitas Negeri Padang, Indonesia
}

\begin{tabular}{l}
\hline \hline Article Info \\
\hline Article history: \\
Received Jun $03^{\text {th }}, 2020$ \\
Revised Sep $21^{\text {th }}, 2020$ \\
Accepted Nov $29^{\text {th }}, 2020$ \\
\hline
\end{tabular}

\section{Keywords:}

Effect of Welding

Preheating

Cast iron

Bending Test

SMAW

\begin{abstract}
Cast iron material is a material that has brittle properties and is less able to withstand stress due to the welding cycle caused by flake graphite in cast iron. Because of these problems, in connecting cast iron materials using the SMAW welding method, it is necessary to have heat treatment (preheating) to avoid the welding problems on the properties of cast iron. The purpose of this study is to determine the effect of heating and non-heating on the cast iron before the welding process. Therefore, this research will play a crucial contribution as a reference for cast iron welding researchers and cast iron welding process. The method of the research was experimental research, where the measurement results were obtained directly from the specimens. The welding was using an open $V$ seam. The specimen used was cast iron with a thickness of $8 \mathrm{~mm}$. One cast iron was given heat treatment at a temperature of $260^{\circ} \mathrm{C}$ and the others did not receive heat treatment before being welded. The welding process used SMAW with CIN - 2 electrodes with a diameter of $3 \mathrm{~mm}$. The test used the bending test on the face specimens according to American Welding Society D1.1 standard. The results showed that there was an effect of the preheating treatment on cast iron, which that the non preheating specimens were easier to fracture than the preheating specimens. Thus, it can be concluded that welding with preheating is better than welding without preheating.
\end{abstract}

\section{Corresponding Author:}

Fauzan Sauri,

Jurusan Teknik Mesin, Fakultas Teknik, Universitas Negeri Padang

Jln. Prof. Dr. Hamka Air Tawar, Padang (25131), Sumatera Barat, Indonesia

Email: saurifauzan@gmail.com

\section{INTRODUCTION}

The role of welding in the production process is increasing every day, due to affordable price, relatively fast, lighter weight, and more varied forms of construction [1]. In addition, in the construction sector, welding is an integral part of the growth and improvement of industry, because it has very important properties in engineering and production improvement [2]. The use of metal in welding that is commonly used is cast iron. Welding method that is often used in the construction world is welding using a shielded metal arc welding method or commonly called SMAW [3]. SMAW welding is widely used to weld carbon steels, low and high alloy steels, stainless steels, ductile iron and cast iron [4]. Cast iron is an iron-carbon alloy with a $\mathrm{C}$ content of more than $2 \%$ and there are other additional elements such as $\mathrm{Si}, \mathrm{Mn}, \mathrm{P}, \mathrm{S}$ depending on the microstructure formed during casting. [5]. Cast iron is widely used in various parts of the machinery industry and the automotive industry. For example pipe fittings, sprockets, pumps, car engines, and several other large size equipments. Cast iron is generally lower in strength compared to cast steel, but certain types of cast iron have a strength that can match the strength of cast steel. The low weldability of cast iron can cause various problems in welding process; especially weld cracks caused by residual stresses [6]. Cast iron is not ready to be welded because it can cause cracking, but this tendency can be reduced when cast iron receives heat treatment [7]. Before the welding process, cast iron must be preheated to prevent cracks and welding defects [8]. The process of welding cast iron mostly uses electric arc welding method with SMAW shielded electrodes, which is a process of joining metal by melting it through heating using an arc electrode [9]. Shielded metal arc welding (SMAW) is the oldest, fastest, most convenient, most commonly used, and produces good quality for the manufacture of various products such as tanks, gears, engines, hulls, mining equipment, boilers [10].

Welding is the process of joining two or more metals with or without the influence of pressure and with or without filler metal [11]. Welding is the joining of two or more metal parts using heat energy which causes the metal around the weld to undergo complicated metallurgical changes, deformations and thermal stresses 
[12]. Welding has a very important role in engineering and repairment of existing metals used by humans. In fact, in today's construction, many welding elements are involved, especially in engineering [13]. Welding involves various variables such as time, temperature, electrode, power input and welding speed which influence the final properties of the weld metal [14]. If the welder is skilled and the welding is carried out according to the procedure, the quality of the welding will definitely be better [15]. In more detail, it is necessary to plan about the welding procedures, the welding examination, the welding material, and the welding type used, based on the function and the designed parts [16]. A quality welding can be obtained if the connection is able to withstand the load or working force. This load or force can be in the form of the bending load that is given to the cast iron being welded, so that the quality and strength of the weld can be seen from the size of the bending load given by using the bending test. The electrode used is a wire wrapped in a protective flux. During welding, this electrode will melt together with the base metal and freeze together to become part of the weld seam [17]. The process of removing metal electrodes occurs when the electrode tip melts and forms grains carried by the electric arc current. When a large electric current is used, the molten metal particles carried will become smooth and conversely when the current is small, the particles become large [18].

The strength of the welding can be affected by the arc voltage, the magnitude of the current, the welding speed, the amount of penetration, and the electric polarity [19]. Welding joints are very important because failure that occurs in welding can be fatal, so that in order to avoid possible failures, the standard of welding results must be increased [20]. To get a good and maximum welding result, a current adjustment is made according to the diameter of the electrode used [21]. This standard represents the minimum acceptance of welding quality based on the test specimen being welded containing more discontinuities [22]. In addition, the polarity factor is one of the parameters in welding, namely a clean surface produces a stronger welding joint. The surface of welding slag must be cleaned because it can affect the welding result [23]. So that it is possible for welding defects to occur. Therefore, it is necessary to do the examination so that the data result will be as expected [24]. The purpose of this study is to determine the effect of welding cast iron with preheating and without preheating using SMAW welding V seam using a current of 70-110 Ampere. The electrode used is CIN-2 with a diameter of $3 \mathrm{~mm}$. This research process discusses how the effect of welding cast iron with preheating and without preheating using SMAW method on the mechanical properties of cast iron using the bending test.

\section{METHOD}

This research was using experimental method. In experimental research, there are dependent variables and independent variables [25]. The dependent variable of the research was cast iron with a thickness of $8 \mathrm{~mm}$ with SMAW welding treatment, the connection used was the $\mathrm{V}$ grove connection, and the current used for welding was 70-100 Ampere. The electrode for welding was CIN-2 according to its use for welding cast iron. The independent variable in this study was heat treatment and without heat treatment of four specimens to be welded. Heat treatment was carried out on two specimens with a temperature of $260^{\circ} \mathrm{C}$ and two specimens without heat treatment. The specimen used was cast iron which was given welding treatment. The welding connection in this study was an open V-shaped joint.

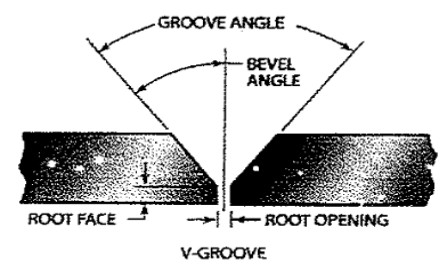

Figure 1 : V seam joint [26]

Open V-shaped joint was used to join plates with a thickness of 6-15 mm with a seam angle between $60^{\circ}$ $-80^{\circ}$, root distance $2 \mathrm{~mm}$, root height $1-2 \mathrm{~mm}$. The seam $\mathrm{V}$ joint was used to weld metal or plates with a

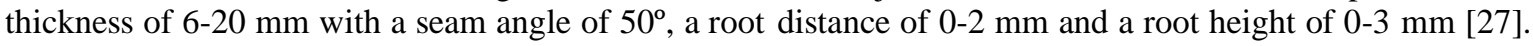
The single $\mathrm{V}$ groove was chosen because of the maximum UTS strength yield compared to other welded joint designs [28]. The following was the procedures in the process of carrying out this research: 


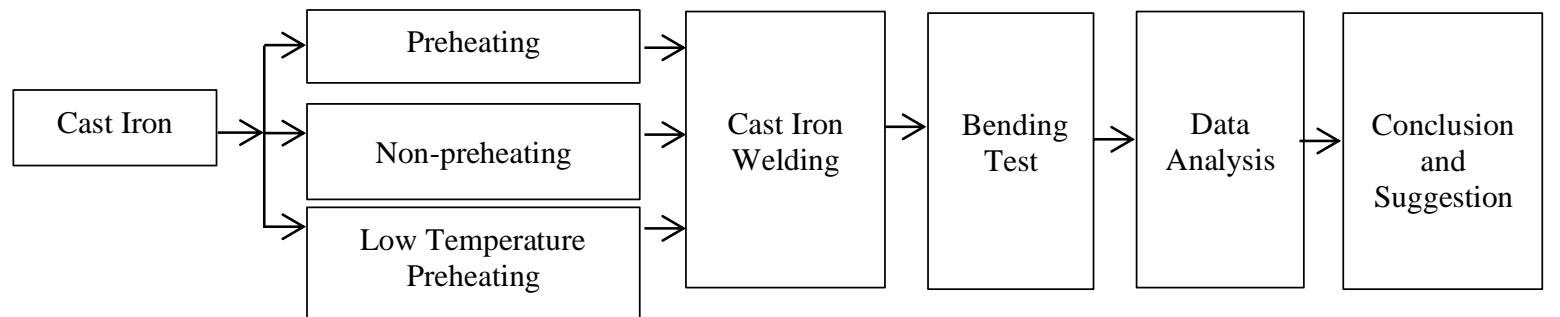

Figure 2 : Research Procedure

The procedure of this research started with the cast iron which was given heat treatment and without heat treatment on the specimens before welding using shielded arc welding. After welding, the cast iron was tested using the bending test and the data were analyzed in accordance with AWS D1.1 standard bending test acceptance. The conclusions and suggestions from the study can be concluded at the end of data analysis. The test specimen used was cast iron which was given heat treatment and not given heat treatment before being welded using the CIN-2 electrode. The following is a picture of cast iron after being welded and formed into a specimen.

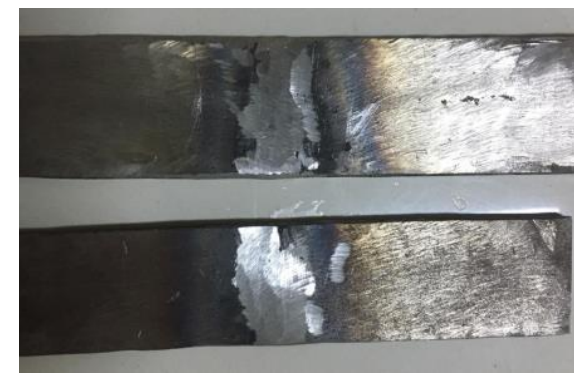

Figure 3 : Dimensions of bending test specimens after welding and shaping

The specimen size is $150 \mathrm{~mm}$ x $40 \mathrm{~mm}$ x $8 \mathrm{~mm}$. Specimens were made by grinding the surface and the root of the weld to get a flat surface as shown in Figure 3. The bending test data was collected by direct observation of the number of discontinuities or symptoms that occurred in the specimens. Then to find out the results of the bending test whether it is accepted or not was carried out based on the acceptance criteria of the standard AWS D1.1 bending test [29].

\section{RESULTS AND DISCUSSION}

Based on the welding results, there were welding defects in the weld metal that was observed by visual examination of the specimens without preheating treatment and specimens with preheating treatment with face bending testing have cracks in the weld metal. Discussion of the results of the bending test on the specimens can be seen in the following figure:

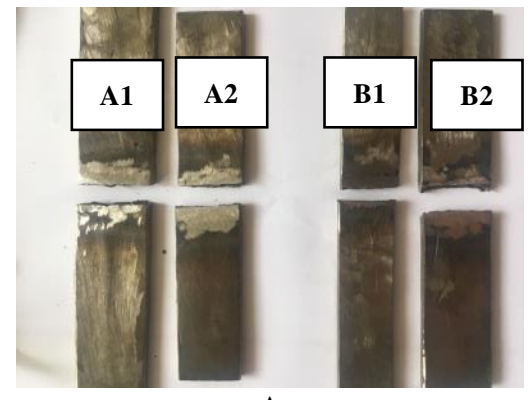

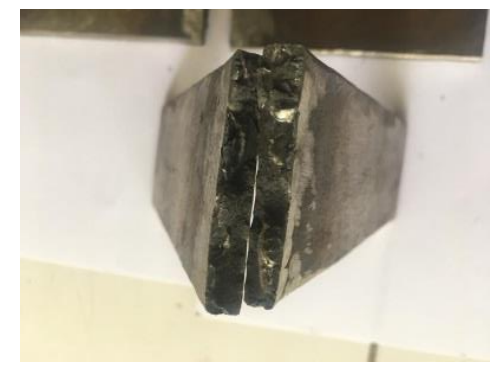

B

Figure 4 : A All Specimens, B. Fracture of Welding Part 
Figure A shows that all of the specimens were broken; this is due to the brittle properties of cast iron and is less able to withstand stress because of the welding process. Specimens without preheating and specimens with preheating were stated as not passed because they had fractures in the weld metal. Figure B is the fracture result of bending testing on cast iron without preheating in the weld metal section.

Table 1 : Bending Test Results

\begin{tabular}{|l|c|c|c|c|c|}
\hline \multirow{2}{*}{$\begin{array}{c}\text { Heating } \\
\text { Temperature }\end{array}$} & \multirow{2}{*}{$\begin{array}{c}\text { Specimen } \\
\text { Code }\end{array}$} & \multirow{2}{*}{$\begin{array}{c}\text { Test } \\
\text { Type }\end{array}$} & \multicolumn{2}{|c|}{ Notes } & Results \\
\cline { 4 - 6 } & & $\begin{array}{c}\text { Type of } \\
\text { Defects }\end{array}$ & Fracture Area & \\
\hline Non-Preheating & $\mathrm{A} 1$ & Face & Broken & Weld Metal & Not Received \\
\cline { 2 - 6 } & $\mathrm{A} 2$ & Face & Broken & Weld Metal & Not Received \\
\hline Preheating & $\mathrm{B} 1$ & Face & Broken & Weld Metal & Not Received \\
\cline { 2 - 6 } & $\mathrm{B} 2$ & Face & Broken & Weld Metal & Not Received \\
\hline
\end{tabular}

The results table above is the bending test results of all specimens. the test shows that the bending test specimens without heat treatment (A1, A2) experienced fractures in the weld metal. While the bending test specimens with heat treatment (B1, B2) experienced fractures in the HAZ area. The acceptance criteria for the bending test based on the AWS D1.1 standard indicate that welding without preheating and welding with preheating is stated not passed, because it experiences fractures or discontinuities in the weld metal area. Thus, it can be concluded that the connection process for cast iron is not suitable for welding.

After conducting the bending test, the researcher can explain that there are differences in welding without preheating and with preheating. Welding without heat treatment experienced fractures in the weld metal section, while welding with heat treatment experienced fractures in the weld metal section close to the HAZ area. There is an effect on both welding results, namely that the cast iron to be welded must be given preheating because this heat treatment will produce a better welding joint.

\section{CONCLUSION}

Based on the results of research that has been conducted, it shows that cast iron is very difficult to weld. This is because the heat generated by electric welding is too fast, causing cracks in the welding area. There is an effect of preheating and without preheating on the quality of the welding as follows: normal welding arc ignition, reducing residual stress, even welding arc width, and also there is an effect of weld toughness by using preheating treatment. The results showed that cast iron with heat treatment is better than cast iron without heat treatment.

\section{REFERENCES}

[1] Cary, H.B, . Modern Welding Technology. 4 th Ed. New Jersey: Prentice Hall, 1998

[2] Trihutomo, P. The Effect of Annealing Process on the welding results on the mechanical properties of low carbon steel. Journal of Mechanical Engineering: 2014: 1: 84-88.

[3] A. Hamid, Analisa Pengaruh Arus Pengelasan SMAW Pada Material Baja Karbon Rendah Terhadap Kekuatan Material Hasil Sambungan, Jurnal Teknik Elektro: 2016: 7 (1); 26-36.

[4] D. Patel, S. Patel, J. Parekh, and S. Chaudhary, A Review on Effect of Different Process Parameters of SMAW, Implementation Journal Interdiscip: 2017; 3 (1); 1384-1389.

[5] Konecna R. Nicoletto G. Bubenko L. Fintova S. A Comparative Study of the fatigue behavior of two heat-treated nodular cast iron. Enginering Fracture Mechanics: 2013: 108-256. Doi 10.1016/j.engfracmech.2013.04.017.

[6] Dieter, George E. Metalurgi Mekanik, Jakarta: Erlangga. 1996.

[7] Daryanto. Teknik Las. Bandung: Alfabeta. 2012.

[8] Bodude, MA. Momohjimoh, I. Studies on Effects of Welding Parameters on the Mechanical. 2015.

[9] Wiryosumarto. Teknologi Pengelasan Logam, Jakarta: Pradnya Paramita. 1991.

[10] J. Verma and R. V. Taiwade. Effect of welding processes and conditions on the microstructure, mechanical properties and corrosion resistance of duplex stainless-steel weldments-A review. Journal of Manufacturing Processes. 2017; 25: 134-152. 
[11] S. Hestukoro, I. Roza, And D. Morfi Nst, Process Analysis Of High Speed Steel Cutting Calculation (HSS) With S45 C Material On Universal Machine Tool. Internatioanal Journal of Innovation. 2018: 3 (1). doi.org/10.24036/tm.v3i1.5572.

[12] Nusulul Huda, Jasman, Pengaruh Kuat Arus Terhadap Uji Tarik Material Baja Karbon Rendah. . Ranah Research. 2019. 2 (1)

[13] Daryanto. Keselamatan Dan Kesehatan Kerja Bengkel. Jakarta: Rineka Cipta. 2007.

[14] Jariyaboon, M., Davenport, A.J., Ambat, R., Connolly, B.J., Williams, S.W., Price, D.A. The effect of welding parameters on the corrosion behaviour of friction stir welded AA2024-T351, Corrosion Science. 2007: 49 (2): 877-909. doi: 10.1016/j.corsci.2006.05.038.

[15] Erizon, N. The effect of welding heat on low carbon steel on physical and mechanical. Ivotek. 2009; 10: 2359-2381.

[16] Kenyon, W. Dasar-dasar Pengelasan, Jakarta: Erlangga. 1984.

[17] Widharto, S. Welding Inspection, Mitra Wacana Media, Jakara. 2013.

[18] A. V. Adedayo, S. A. Ibitoye And O. A. Oyetoyan, Annealing Heat Treatment Effects On Steel Welds; Journal Of Minerals And Materials Characterization And Engineering. 2010: 9 (9): 547-557.

[19] Talabi, S.I.A, Owolabi, O.B.Effect Of Welding Variables On Mechanical Properties Of Low Carbon Steel Welded Joint. Journal Of Advances In Production Engineering \& Management. 2013: 9 (4): 181-186. Doi.Org/10.14743/Apem2014.4.186, 2013.

[20] Kenyon, W. Dasar-dasar Pengelasan, Jakarta: Erlangga. 1984.

[21] Karadeniz, E., Ozsarac, U., Yildiz, C. The Effect Of Process Parameters On Penetration In Gas Metal Arc Welding Processes, Materials \& Design. 2007: 28 (2): 649-656 Doi:10.1016/J.Matdes..07.014. 2005.

[22] R. S. Funderburk. Key Concepts In Welding Engineering. Welding Innovation. 1997: Vol. XIV, no. 2.

[23] Despa, Wandri, Purwantono, W. Pengaruh Arus AC dan DC Terhadap Hasil Pengelasan Pada Las Busur Listrik. Jurnal Pendidikan Teknik Mesin. 2016: 1-7.

[24] Ferry Budhi Susetyo, Ja'far Amirudin, Studi Karakteristik Pengelasan Smaw Pada Baja Karbon Rendah St 42 Dengan Elektroda E 7018. 1St Ed. Jakarta : Jurnal Konversi Energi Dan Manufaktur UNJ. 2013.

[25] Sonawan, H., Suratman, R. Pengantar Untuk Memahami Pengelasan Logam, Bandung; Alfa Beta. 2004.

[26] Jeffus, Larry. Welding: Principles and Application. Clifton Park, N. Y. : Delmar Cengage Learning. 2012.

[27] S. Nutalapati, D. Azad, and G. S. Naidu, Effect of Welding Current on Welding Speed and Ultimate Tensile Strength (UTS) of Mild Steel, Internationl Journal Mechanical Enginering. 2016: 7 (5): 156176.

[28] M. Bin Afan, P. Purwantono, M. Mulianti, and B. Rahim, Pengaruh Suhu Penyimpanan Elektroda Low Hydrogen E7016 terhadap Hasil Uji Tekuk Sambungan Las Pelat Baja Karbon SS400, Jurnal Rekayasa Mesin. 2020: 15 (1): 20-25, doi:10.32497/jrm.v15i1.1823.

[29] American Welding Society. Structural Welding Code-Steel. D1.1/D1.1M. 2015. 